Full reference: Adhikariparajul, M., Hassan, A., Fletcher, M., \& Elamer, A.A. (2020) 'Integrated Reporting in Higher Education: Insights from Scotland, Northern Ireland and Wales', Social

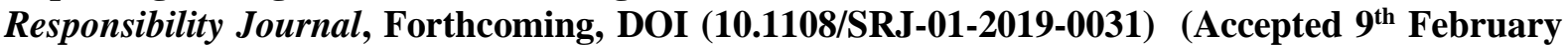
2020).

\title{
Integrated Reporting in Higher Education: Insights from Scotland, Northern Ireland and Wales
}

\author{
Mahalaximi Adhikariparajul ${ }^{\mathrm{a}}$, Abeer Hassan ${ }^{\mathrm{a} *}$, Mary Fletcher ${ }^{\mathrm{a}}$ and Ahmed Elamer ${ }^{\mathrm{b}}$ \\ ${ }^{a}$ Accounting, Finance and Law Unit, Institute for Accounting and Financial Markets, School of Business and \\ Enterprise, University of the West of Scotland, Paisley, PA1 2BE, UK \\ ${ }^{\mathrm{b}}$ Brunel Business School, Brunel University London, Kingston Lane, Uxbridge, London, UB8 3PH UK; and \\ Department of Accounting, Faculty of Commerce, Mansoura University, Mansoura, Egypt
}

\footnotetext{
*Address for correspondences

Dr. Abeer Hassan

Senior Lecturer in Accounting and $\mathrm{PhD}$ coordinator

School of Business and Enterprise;

G226, Gardner Building,

University of the West of Scotland

PAISLEY; PA1 2BE

Tel: +44 (0)141 8483361

Fax: +44 (0)1418483395

email:abeer.hassan@uws.ac.uk
} 


\title{
Integrated Reporting in Higher Education: Insights from Scotland, Northern Ireland and Wales
}

\begin{abstract}
Purpose - This paper examines the level of disclosure on content elements of Integrated Reporting (IR) in Scotland, Northern Ireland and Wales Higher Education Institutions (HEIs). We suggest that integrated thinking is an internal process that organizations can follow to produce integrated reporting that can be used as an effective mechanism to enhance accountability with stakeholders.
\end{abstract}

Design/methodology/approach - International Integrated Reporting Council (IIRC) guidelines and content analysis are used to analyse IR content elements in HEI reports from 2014-2016.

Findings- The results indicate a significant increase in the trend and extent of IR content elements. The HEI specific characteristics examined, such as the establishment of HEI; adoption of IR framework and governing board size are all statistically and positively associated with IR content elements disclosure. This paper introduces signalling theory to explore the idea that appropriate communication via integrated thinking can close the gap between the organization and its stakeholders via increased level of disclosure on IR content elements.

Practical implications- The results will assist policymakers and regulators to assess the benefits of voluntary implementation of IR at HEIs and evaluate possible mandatory implementation of IIRC guidelines. Second, the findings can assist managers of institutions interested in implementing integrated reporting.

Social implications- The study recommends universities to explicitly address IR issues in reporting as this will increase their impact as leaders of educational thought in addition to their roles as partners, advisors, counsellors and assessors.

Originality/ value- The study explores whether HEIs in Scotland, Northern Ireland and Wales provide disclosure on IIRC content elements as a reflection of integrated thinking and whether the connectivity and interdependence between different departments will help to signal to stakeholders how HEIs create value for society.

Keywords- Integrated Reporting, integrated thinking, Higher Education Institutions, content analysis, signalling theory

Paper type- Research paper 


\section{Introduction}

Although universities are places of education, vessels for researchers, crucibles for innovators and receptacles for leadership, they are poor at communicating their contribution and valueadded to wider society (British Universities Finance Directors Group (BUFDG), 2016). This research examines the evolution of corporate reporting by HEIs towards a more integrated approach, termed Integrated Reporting (IR) (Paloma Sanchez et al., 2009; Fonseca et al., 2011; Hinson et al., 2015; Sangiorgi and Siboni, 2017; Brusca et al., 2018; Ferrero-Ferrero et al., 2018). The main motivation for this study is that higher education has its own specific challenges - including international competition, student recruitment, research funding and student expectations - that make the connection and the interdependence between its departments, through integrated thinking, crucial to provide relevant information to stakeholders on value creation via integrated reporting (BUFDG, 2016). The provision of this relevant information will lead to better communication between the organization and its stakeholders, supporting a signalling theory interpretation (Zutshi et al., 2018). Therefore, we are suggesting that integrated thinking is an internal process that organizations can follow to produce integrated reporting that will be used as a communication tool with stakeholders. Additionally, since the inception of IR, it has been of more interest to public sector researchers than public sector organizations, suggesting a lack of awareness of the potential value of IR to the public sector.

The main objective of this paper is to better understand whether HEIs in Scotland, Northern Ireland and Wales provide disclosure on one of International Integrated Reporting Council (IIRC) guidelines - content elements - as a reflection of integrated thinking and whether the connectivity and interdependence between different departments will signal to 
stakeholders how HEIs create value for society (Secundo et al., 2016; Higgins et al., 2019; Zutshi et al., 2018).

The main contribution of this study is to address four different aspects of IR. First, this paper contributes to the link between integrated reporting and integrated thinking research (Katsikas et al., 2016; Adams, 2017; Rinaldi et al., 2018). Second, the research introduces signalling theory to promote the idea that appropriate communication via integrated thinking can close the gap between the organization and its stakeholders via disclosure (Zutshi et al., 2018). Third, our paper investigates whether the disclosure of IR content elements reflects the implementation of an integrated thinking approach (Higgins et al., 2019; Stacchezzini et al., 2019). Fourth, it investigates IR in HEIs as suggested by Adams, (2018). Fourth, our paper is a response to call for research on IR adoption in UK HEIs (Adams, 2018). This is because there are few prior IR studies in the HEIs implemented in other countries. For example, Veltri and Silvestri, (2015) investigated IR in Free State University in South Africa. Chatelain-Ponroy and Morin-Delerm, (2016) in France, Nomura and Abe, 2010 (Japan). To the best of the authors' knowledge, this study is one of the few that investigates IR content elements in the HEI sector (Hassan et al., 2019). Our paper is an extension of the study by Hassan et al. (2019)that focuses on IR in UK higher education from an institutional theory perspective. However, our study employs signalling theory to investigate whether the increased level of disclosure on IR content elements is a reflection of integrated thinking. Also, most of the sample data (80\%) in the study by Hassan et al. (2019) comes from English universities, which may drive the results. We extend and complement their line of research by adopting signalling theory perspective to examine whether the increased level of disclosure on IR content elements is a reflection of implementing integrated thinking. The research employs content analysis based on annual reports published between 2014 and 2016 and the HEIs selected for this study are situated in Scotland, Northern Ireland and Wales. 
This paper will proceed as follows: the next section will explain the link between integrated reporting and integrated thinking. This is followed by a discussion on signalling theory in higher education. The following section provides a literature review on IR and develops the hypotheses. The paper then turns to the methods and empirical findings derived from the comparative analysis of HEI annual reports. The results are discussed and in the final section, the paper draws conclusions and provides recommendations for future research.

\section{Integrated Reporting and integrated thinking}

Integrated reporting (IR) has been developed to provide a combined disclosure of financial and non-financial information. This is achieved by the publication of a single report from the perspective of stakeholders (King IV, 2016; Soh et al., 2015; Reimsbach et al., 2017).

Integrated thinking, on the other hand, is defined as "the reflection of connectivity and interdependencies between various factors which affect an organisation's value creation capacity" (King IV, 2016 p. 13). The IIRC (2013) asserts that integrated thinking supports integrated decision making and actions for short, medium and long-term value creation by making an active relationship between different operating and functional units. Recently, there is a number of studies address integrated thinking. For instance, Del Baldo, (2017) points out that integrated thinking is linked to the strategic management process and can facilitate organizational operation by changing the whole organizational culture through collaboration between different internal units to gain a better understanding and appreciate the impact of their behaviour and decision on their organization`s stakeholders. Moreover, it is argued that by using an integrated thinking approach, organizations can switch to forward-thinking to report future growth prospects and deal with uncertainty (Alberti-Alhaybat, 2018; Massingham et al., 2019). Additionally, internal communication can lead to the development of integrated thinking as organizations embed economic, sustainability and governance-related performance within their strategic and operational processes (Camilleri, 2018; Higgins et al., 2019). 
Another stream of studies explores the link between integrated thinking and integrated reporting. The study of Katsikas et al. (2016) suggests that in order to adopt IR in practice, companies should develop integrated thinking inside the organisation and related disclosures should be the final step towards IR. In this vein, Adams (2017) suggested steps that should be followed in integrated thinking and IR: 1) developing an understanding of sustainable development issues within the organizations external environment; 2) identifying material sustainability issues; 3) developing a business model to connect strategy and sustainability; 4) developing integrated thinking, 5) connectivity and governance; 6) and preparing the integrated report. Rinaldi et al. (2018) argue that an organization`s integrated thinking and IR are strongly linked and that IR is an effective mechanism of enhancing accountability. Likewise, the Chartered Institute of Management Accountants (CIMA, 2017), suggest that IR is the output of integrated thinking which enables organizations to "live their story" rather than merely "tell it". In addition, the studies of Guthrie et al. (2017) and Cavicchi et al. (2019) recommend the implementation of integrated thinking in the public sector.

In terms of applying integrated thinking in higher education, in their case study of a South African university, Veltri and Silvestri (2015) argue that if HEIs manage to disclose business as a whole, providing relevant information to their stakeholders in a concise, consistent and comparable format by adopting integrated thinking as internal cultural and organisational mechanism, they will achieve competitive advantage where they are able to differentiate their position from others with consequent reputational benefits. However, in the context of Spanish HEIs, Brusca et al. (2018) suggest that HEIs do not embed integrated thinking within the organization and that IR should be considered as a further step on the sustainability journey. Adams (2018) finds that although universities have the biggest impact of society and the largest beneficiaries of integrated thinking and IR, UK universities are not fully rising to the challenges as set by IIRC (2013). However, those UK HEIs who participate 
within the advanced higher education integrated thinking and IR project spent valuable time discussing the meaning of value creation for HEIs and their stakeholders (Adams, 2018). In this context, the BUFDG report (2016) emphasises that HEIs, in particular, have an interesting story to tell their stakeholders about the importance of their role and the connections and relationships between all the factors that affect the ability of HEIs to create value over time.

Therefore, the consensus of the literature suggests that for HEIs in Scotland, Northern Ireland and Wales to produce integrated reporting, they should follow an integrated thinking approach. Our investigation of the disclosure on IR content elements will show the connectivity and interdependencies as a reflection of integrated thinking, leading to the provision of increased disclosure. This is because disclosure on the content elements (such as external environment, governance, risk and opportunities, performance, outlook, etc.) brings together information from a wide range of different departments in the organization.

\section{Review of the literature}

\subsection{Signalling theory in higher education}

Mahoney (2012) and Mahoney et al. (2013) argue that there are several theories addressing the association between voluntary disclosures and performance, which are generally consistent with either a voluntary disclosure perspective to which signalling theory ${ }^{l}$ belongs, or theories grounded in a socio-political perspective to which greenwashing ${ }^{2}$ belongs (e.g. Hassan and Guo, 2017). Signalling theory assumes that disclosure is costly, and companies will disclose only when the benefits outweigh the associated costs (e.g. Verrecchia, 2001). It deals with differences of information between stakeholders and the organizations and promotes the idea

\footnotetext{
${ }^{1}$ Signalling theory is “....useful for describing behaviour when two parties (individuals or organizations) have access to different information. Typically, one party, the sender, must choose whether and how to communicate (or signal) that information, and the other party, the receiver, must choose how to interpret the signal (Connelly, et al., 2011, p.39)'”.

2 Greenwashing "involves selective disclosure of positive sustainability actions resulting in misleading and biased reporting" (Mahoney et al., 2013, p. 352). Greenwashing is a practice that is deceptively used to promote the perception that a company's policies or products are environmentally friendly, when arguably they are not (Lewis, 2016).
} 
that appropriate communication can close the gap between the organisation and its stakeholders. In the context of higher education, signalling theory proposes there is asymmetry of information mostly in favour of universities (Connelly et al., 2011; Taj, 2016; Zutshi et al., 2018). This imbalance would ideally be the motivation for the university to publicly communicate and transmit the helpful information to relevant stakeholders. And, yet, this natural rebalancing does not always occur as expected (Veltri and Silvestri, 2015; Zutshi et al., 2018). However, based on our discussion in the previous section, we would expect that if universities implement integrated thinking to signal to stakeholders how HEIs create value for society (Secundo et al., 2016), this will be reflected as an increase in the level of disclosure on IR content elements and will enhance their accountability (Rinaldi et al., 2018). Also, integrated thinking as a tool for connectivity and interdependence between different departments will eliminate the imbalance and clearly articulate the value creation in the HEI sector (Adams, 2018). This is because if managers are engaged in integrated thinking, HEIs can demonstrate interconnectivity between strategy, strategic objectives, risk and incentives, breaking down the barriers between departments and stimulating dialogue within different teams contributing to holistic corporate report (Stacchezzini et al., 2019). This simply means an increase in the level of disclosure on IR content elements.

\subsection{Integrated reporting}

For the purpose of this study, prior pieces of literature are classified into three groups. The first group covers the IR framework, the second one covers IR in the public sector, and the third group covers IR in the higher education sector.

The first group of studies covers the IR framework and address its three components: fundamental concepts; guiding principles; and content elements IIRC (2013). Some researchers focus on the fundamental concepts of IR (Humphrey et al., 2017; Adams, 2017; Oll and Rammerskirchen, 2018; Liu et al., 2019). The findings of these studies reveal that the 
integration of sustainability information and value creation reporting is highly influenced by the IR framework. In addition, while some studies are based on the guiding principles (Mio et al., 2016; Ruiz-Lozano and Tirado-Valencia, 2016; Oll and Rammerskirchen, 2018), others are based on the content elements (Mass et al., 2016; Pavlopoulos et al., 2017). Even though the IR practice is still in the early stages, some prior researchers have taken a qualitative approach and explore the implications of IR based on semi-structured interviews (Wee et al., 2016; Feng et al., 2017; Trébuca et al., 2017; Maroun, 2018; Stacchezzini et al., 2019). In this context, Bananuka et al. (2019) explore the reason for slow IR adoption in Uganda as a developing country and the factors that need to be emphasized to ensure firms are embracing the practice of IR. The results reveal that because of scarce resources, culture and leadership, stakeholder`s demand, the regulatory requirement, effect of globalisation and the mindset, lack of awareness of IR, nature of business and size of organisation, IR adoption is slow in developing countries. Melloni et al. (2017) investigated the disclosure of conciseness, completeness, and balance in IR. The research findings indicate that firms are struggling to produce concise, complete and balanced reports. More interestingly, firms with lower financial performance tended to produce longer, more complex IR whereas firms with lower social performance disclosed less on the sustainability topic.

The second group of studies cover IR in the public sector. Cohen and Karatzimas (2015) provide a conceptual contribution to the debate about IR as the future form of corporate reporting in the Greek public sector. The research concludes with a recommendation that government entities publish information on IR regularly and that the provision of such information should be concise and comprehensive. The case study of Guthrie et al. (2017) explores the connection between IR, integrated thinking and the internal mechanism of change in the Italian public sector. Montecalovo et al. (2018) examine the influence of IR on the sustainability practice in the enterprises owned by the state in New Zealand. The results 
indicate that the sustainability disclosure quality was steady during the study period. In a case study based at an Italian university hospital, Cavicchi et al. (2019) investigate IR mechanisms that affect the potential development of IR practice in the Italian health care sector. The findings indicate that there is limited implementation of IR in the health care sector and that IR framework adoption is only possible when the major stakeholders are involved in the decisionmaking process.

The third group of studies cover IR in higher education. Veltri and Silvestri (2015) conducted a pioneering study into The Free State University IR in South Africa in 2012. The research findings show that the university content elements did not follow in practice the intended meaning of the IIRC framework as content elements and guiding principles. More interestingly, the findings show that the content elements did not have an outward-looking orientation, nor were they interconnected, and furthermore, there was a lack of information on stakeholder relationships and value creation. Brusca et al. (2018) explore IR and sustainability reporting at the HEIs in the voluntary reporting context of an innovative Spanish university. This case study analyses the development of sustainability reporting and IR at the university and the results indicate that the report mainly focused on sustainability and social value, rather than connecting all capitals from the IR framework and that integrated thinking was not embedded within the organisation. Our study will contribute to the three groups of prior research as it covers IIRC content elements in HEIs as public sector organizations.

\section{Development of hypotheses}

\subsection{Establishment of HEIs}

The establishment of universities classifies UK universities into two main groups: universities established pre-1992 (old universities) and universities established post-1992 (new universities). Previous studies relating disclosure to the period of establishment of HEIs provide no conclusive results. One group of studies finds that pre-1992 HEIs disclose 
significantly more financial and research information than their post-1992 counterparts, but there are no significant differences between pre- and post-1992 institutions regarding the overall disclosure level (Maringe, 2009; Lomas, 2006; Ntim et al., 2017). The other group suggests that post-1992 universities are more open towards improving the quality of teaching and learning, internationalisation and adoption of modern technology for teaching and communication. Asaad et al. (2013) find that post-1992 universities have a high volume of teaching income that includes income from international students. Lomas (2006) argues that post-1992 universities improve the quality of teaching and learning, including success in the adoption of a Virtual Learning Environment (VLE) approach.

Although post-1992 universities are increasing the disclosure of their activities and the gap between the two groups may be closing, they may still be in the process of realising the advantages of disclosing across the wide range of their activities, and furthermore, may not be able to devote as much time and resources as pre-1992 universities to assembling the content required to create this narrative. To the best of our knowledge, this is the first study to examine the impact of the period of establishment of HEIs on the disclosure level of integrated reporting in Scottish, Northern Irish and Welsh HEIs. Based on the above discussion, the present study investigates whether the period of establishment of the HEI (before or after 1992) has an effect on the level of disclosure of the integrated reporting content elements. This leads to the first hypothesis of the current study:

H1. Older established universities (pre-1992) are more likely to provide disclosure on IR content elements disclosure than newly established universities (post-1992).

\subsection{IR adoption}

Prior studies on IR adoption do not provide consistent results. While the study of Melloni et al. (2017) provide evidence that in practice, corporations are struggling to produce a concise, 
complete and balanced report, the study of Ahmed Haji and Anifowose (2017) concludes that corporate disclosure increased after IR adoption. In addition, other studies criticise the adoption of IR. For example, the study of Gunarathe and Senaratne, (2017) found that IR is a transition from sustainability reporting rather than a transformation and conclude that corporations need more guidance in the process to achieve integrated thinking in practice. The study of Veltri and Silvestri (2015) also finds that the South African Free State University`s IR related content elements and guiding principles do not reflect the meaning and intentions of the IIRC Framework. However, BUFDG (2016) provide evidence that UK universities are beginning to prepare higher-quality integrated reports but that more practice is needed in critical analysis and creativity to draw out the narrative from the figures and tell their stories. Therefore, it is expected that IR adoption will exercise a positive influence on the level of IR content elements disclosure. Hence, the second hypothesis is formulated.

H2. There is a positive relationship between university adoption of $I R$ and the level of disclosure on IR content elements.

\subsection{League table performance}

University ranking and its position in the league table has become important for public accountability (Berbegal-Mirabent and Ribeiro-Soriano, 2015; Gibbons et al., 2015). These rankings supply information on the measurable dimension of service quality and encourage institutional transparency including stimulating a culture of quality assessment in education. Furthermore, Gibbons et al. (2015) have demonstrated that the National Student Survey has a statistically significant impact on student applications. Christie (2016) also provides evidence showing the significance of league tables in contributing to establishing a trustworthy status, employment measurement and comparisons with other stakeholders. The Guardian League Table (2017) indicators are for satisfaction with course, satisfaction with teaching, satisfaction with feedback, student allocation, student spending allocation and average entry tariff. This 
research argues that information disclosure may be affected by league table ranking position and this leads to the third hypothesis:

H3. There is a positive relationship between university performance position ranking in league tables and the level of disclosure on IR content elements.

\subsection{University governing board size}

Gallego-Alvarez et al. (2011) examine the relationship between information disclosure and size, leverage, university profitability, governance board size, internationality of university, age of university and other explanatory variables within 70 Spanish universities. A content analysis method was used, and they concluded that board size is statistically insignificant and does not influence the university's information disclosure. This suggests that disclosure in universities is not influenced by similar parameters which are behind corporate disclosure in businesses.

Ntim et al. (2017) explore the influence of corporate governance towards the extent of voluntary disclosure. 130 UK HEI annual reports were analysed with the variables of governing board size; board meeting frequency; membership diversity; quality of the board audit committee and audit firm quality. The research used a multi-theoretical framework and descriptive analysis, including ordinary least squares regression models. The findings indicated that audit committee quality, governing board diversity, governor independence and the presence of governing committee do not influence HEI voluntary disclosures. This suggests that university corporate board size does not have any influence on voluntary disclosure. Therefore, the fourth hypothesis is as follows:

H4. There is no relationship between university governing board size and the level of disclosure on IR content elements. 


\section{Methodology}

\subsection{Data selection}

Our population consists of 26 HEIs in Scotland, Northern Ireland and Wales. The list of HEIs was taken from the Complete University Guide (2017) and used to collect data for academic years 2013/14, 2014/15 and 2015/16 respectively. Thus, our evidence was obtained from 26 HEIs over 3 academic years (78 observations). This study covers data collected from the annual reports prepared by HEIs located in Scotland, Northern Ireland and Wales in comparison to prior studies. We collect various secondary data types associated with HEI sector-specific features and IR content elements disclosure. The control variables used for this study involved the selection of datafinancial variables collected from HEI websites, HEI annual reports, and other publicly available information.

\subsection{Research variables}

Integrated Reporting disclosure index (dependent variable). We follow prior literature on HEIs that used content analysis to examine the level of disclosures (Gallego-Alvarez et al., 2011) and in the UK (Ayoubi and Massoud, 2007; Jiang and Carpenter, 2013; and Low et al., 2015). The current study follows this practice to analyse voluntary disclosure in the UK HEI sector.

To construct the disclosure index, we followed the IR framework provided by the IIRC (2013) and recently adopted by the BUFDG (2016) and focused only on the integrated reporting content elements. According to the IIRC, an integrated report includes eight content elements which are as follows: organisational overview and external environment, governance, business model, risk and opportunities, strategy and resource allocation, performance, outlook and basis of preparation and presentation (IIRC, 2013). A pilot study was conducted and examined six HEIs including their annual reports. Three researchers from three different 
universities independently reviewed disclosure scores, with any scoring differences discussed and reconciled (See Appendix 1 for the disclosure index).

This research adopted the weighted scoring method for disclosure indices and this assigns a weight to each item to consider the variation in the importance of each type of information (Cheung et al., 2010). This is structured as follows: no disclosure $=0$, descriptive disclosure without any link to strategy, governance, performance and prospect=1, descriptive disclosure and link with all strategy, governance, performance and prospect compare with historic position $=2$, descriptive disclosure linked with all strategy, governance, performance and prospect compare with historic, present and future position $=3$. The total disclosure score of IR content elements disclosed in HEI annual reports integrated reporting score is the dependent variable.

Independent variables. The researchers also collected data on (1) HEI sector-specific features comprises time of establishment of the HEI (ESTB) (Ntim et al., 2017; GallegoAlvarez, et al., 2011); (2) IR framework adoption (IRFA) (Gunarathe and Senarathe, 2017; Solomon and Maroun, 2012); (3) league table position ranking (LTR) (Christie, 2016); and (4) the number of members in the governing board (BSIZE) (Ntim et al., 2017; Gallego-Alvarez, et al., 2011).

Control variables. To reduce the potential of omitted variable bias (Aburaya, 2012), the following control variables have been also collected: (1) council funding (FUND); (2) growth in total income (GWTH); (3) HEI liquidity (LIQD); (4) HEI total assets (SIZE); and (5) total endowment assets (TEA). Due to the cross-sectional nature of the data collected, the empirical analysis commences with descriptive statistics, correlation and regression analysis (see Table 1 for the measurement of the research variables). Table 1 classifies the research 
variables used in $H 1$ - $H 4$ for three years 2013/14, 2014/15, 2015/16 and explains the variables measurement process.

\section{Insert Table 1 here}

\subsection{Data analysis and model specification}

Data analysis proceeds in five steps. First, descriptive statistics of all study variables are calculated, including mean, median, standard deviation, min, max, frequencies and quartile. Second, the total integrated reporting content elements' disclosure score for research data is offered. Third, t-test and chi-square tests are employed to discover relationships between integrated reporting content elements and establishments of higher education institutions. Fourth, Spearman correlation coefficients are calculated between study variables. Lastly, hypothesis testing is conducted via ordinary least squares (OLS) regression to estimate the influence of explanatory variables on providing disclosure on the content elements of the integrated reporting. Generally, OLS regression is well suited for testing our hypotheses and in line with previous studies (Alshbili et al., 2019; Elamer et al., 2017, 2018, 2019; Elmagrhi et al., 2019). The regression model is specified as:

$$
\begin{aligned}
& \text { TOTAL }=\beta_{0}+\beta_{1} E S T B+\beta_{2} I R F A+\beta_{3} L T R+\beta_{4} S I Z E+\beta_{5} B S I Z E+\beta_{6} G W T H+ \\
& \beta_{7} F U N D+\beta_{8} L I Q D+\beta_{9} T E A+\varepsilon
\end{aligned}
$$

Where TOTAL is total IR content elements disclosure score; ESTB refers to establishment of HEI (before or after 1992); IRFA refers to the IR framework adoption; LTR refers to performance position ranking in the league table; BSIZE refers to number of members in HEI governing board and control variables of total assets depicted as SIZE; percentage of current periods total income minus previous periods total income to previous periods total income is given as $G W T H$; percentage of total annual council funding income to total annual income is referred to as FUND; current assets divided by current liabilities is LIQD; and the percentage 
of total annual endowment assets to total annual assets is TEA. Also, the statistical programs SPSS and Stata are used in analysing our data.

\section{Results and Discussion}

\subsection{Descriptive statistics}

Table 2 presents the summary of descriptive statistics for the dependent variables, independent variables and control variables. It also presents the statistics of the eight themes of IR content elements. Evaluation of the summary's descriptive statistics indicates rather interesting findings. There was a large degree of variability in the summary of IR content elements disclosure in the HEI sector which aligns with the findings of prior studies (Gallego-Alvarez et al., 2011; Ntim et al., 2017). The scores range from a minimum of 2 to a maximum of 18 in some themes and ranges from 26 to a max of 105/168 for the total IR content elements scores and widespread distribution is depicted in Table 2. Total disclosure relating to the league table ranking position $(L T R)$ intervals range from a minimum of 0 to maximum of 125 and total disclosure related to HEI governing board size (BSIZE) reveals from a minimum of 15 to maximum of 38 .

\section{Insert Table 2 here}

\subsection{Analysis of integrated reporting content elements disclosure index}

We carried out two different types of analysis to present the integrated reporting content elements disclosure index. First, we presented the total scores over the selected three years of the study $(2013 / 14,2014 / 15$, and 2015/16) for the 26 universities in our data (see Table 3). The results show that there is a large degree of variability in total scores achieved by our data. Scores range from a minimum score of 26 (achieved by University No. 16) and a maximum score of 89 (achieved by University No.13) in 2013/14. There is a slight difference in this variability in 2014/15 with scores ranges from a minimum score of 32 (achieved by the 
University No. 26) and a maximum score of 99 (achieved by the University No. 9). In 2015/16, scores range from a minimum score of 43 (achieved by the University No. 26) and a maximum score of 105 (achieved by the University No. 9).

The results also show that there is an increase in the level of disclosure on integrated reporting content elements provided by our d data over the years. We noticed that some universities have dramatically improved their level of disclosure on integrated reporting content elements between 2013/14-2015/16 as some universities achieved over 188\% increase in the level of disclosure. For example, University No. 2 scored 34 in 2013/14 and managed to achieve 98 in 2015/16 (188.24\% increase). We interpret the increase of the level of disclosure on IR content elements as a reflection of implementing an integrated thinking approach. This is because content elements themes (governance, risk \& opportunities, performance, outlook, etc.) bring together information from different departments and this shows the connectivity and interdependencies as a reflection of integrated thinking. This can also break down the barriers between departments, stimulating dialogue within different teams as they prepare the integrated report (Stacchezzini et al., 2019).

\section{Insert Table 3 here}

Secondly, we ran t-test and chi-square tests to investigate if there are any differences in the level of disclosure of integrated reporting content elements and the date of establishment (ESTB) of the higher education institutions (pre and post-1992). Table 4 presents the totals of the eight themes (Organisational Overview and External Environment (OEE); Governance $(G V N)$; Value Creation Model (VCM); Risk and Opportunity $(R O)$; Strategy and Resource Allocation $(S R A)$; Performance $(P M)$; $(7)$ Outlooks $(O L K)$ and Basis of Preparation and Presentation $(B P P))$. This because we felt that the total of each theme is enough to explain the results. However, a full analysis of t-test and chi-square tests of all the disclosure items of our index is available upon request. These findings indicate that, in general, pre-1992 HEIs provide 
more disclosure on integrated reporting content elements. Both t-test and chi-square tests identify significant differences ( $\mathrm{t}$-test $\mathrm{p}=.005$ and chi-square $\mathrm{p}=.006$ ) between pre and post 1992 institutions with regard to 7 items. OEE (t-test $p=.002$ and chi-square $p=.002)$. VCM (t-test $\mathrm{p}=.003$ and chi-square $\mathrm{p}=.004) . \mathrm{RO}$ (t-test $\mathrm{p}=.029$ and chi-square $\mathrm{p}=.030)$. SRA $(\mathrm{t}$ test $\mathrm{p}=.085$ and chi-square $\mathrm{p}=.085)$. PM (t-test $\mathrm{p}=.010$ and chi-square $\mathrm{p}=.011)$. OLK (ttest $\mathrm{p}=.000$ and chi-square $\mathrm{p}=.000)$. BPP (t-test $\mathrm{p}=.011$ and chi-square $\mathrm{p}=.011$ ). Collectively, the above findings indicate that pre-1992 HEIs provide higher levels of disclosure than their post-1992 counterparts. This supports H1: Older established universities (pre-1992) are more likely to provide disclosure on IR content elements disclosure than newly established universities (post-1992).

\section{Insert Table 4 around here}

\subsection{Correlation matrix}

Table 5 presents the correlation matrix for the variables used in our regression analysis to test for multicollinearity and we also report the Spearman's nonparametric coefficient. The results show that there is a positive but not significant relation between Total IR and HEI governing board size BSIZE (0.124) and a significant negative relation with the league table ranking position (-0.046). In terms of the control variables, the results show no relation between growth GWTH (0.046), funding FUND (0.013) and total endowment assets TEA (-0.018). However, there is a positive significant relationship between total IR and HEI total assets SIZE $(0.284)$ but a negative relation between total IR and liquidity $\operatorname{LIQD}(-0.205)$.

\section{Insert Table 5 around here}

\subsection{Multivariate Results}

Table 6 presents the regression results for the relation between Total IR and all research variables. 
Establishment of HEI and Total IR disclosure. Model 1 of Table 6 shows that the establishment of HEI is positively and significantly associated with Total IR disclosure. This supports the argument that the HEIs established before 1992 have more IR content elements disclosure compared with the HEI established after 1992. Maringe (2009) found that due to increasing competition and change in HEI funding since 2006, the pre-1992 universities in the UK changed the content of corporate reporting to attract talented people from around the World. Ntim et al. (2017) found that the HEIs established before 1992 disclose significantly more financial and research information compared with the HEIs established after 1992. Our results are in line with the finding of Hassan et al. (2019) that pre-1992 universities employ integrated reporting and thinking to gain stakeholders' trust. Therefore, the above results suggest that there is strong support for H1: (Older established universities (pre-1992) are more likely to provide disclosure on IR content elements disclosure than newly established universities (post-1992)). Our interpretation for this result is that there is evidence that the pre1992 HEI departments and units are more active than post-1992 universities in connecting and collaborating, reflecting integrated thinking, and describing the impact of their behaviour on their stakeholders via integrated reporting, supporting a signalling theory interpretation (Del Baldo, 2017).

Integrated reporting framework adoption and Total IR disclosure framework.

Model 1 of Table 6 also displays the regression results for the relation between the IR framework adoption (IRFA) and Total IR disclosure. Our results show that there is a positive relationship between integrated reporting framework adoption (IRFA) and Total IR disclosure $(t=3.12)$. This result is in line with numerous prior studies which find a positive relation between integrated reporting framework adoption and Total IR disclosure (Melloni et al., 2017; Pavlopoulos et al., 2017; Hassan et al., 2019). Additionally, Feng et al., (2017) suggested that the integrated reporting framework is significantly well developed to drive organisational 
reflection or reporting and attract wider corporate engagement. This provides support for $\mathrm{H} 2$ : (There is a positive relation between university adoption of IR and the level of disclosure on IR content elements). Our interpretation for this result is that there is evidence that those HEIs that adopt IR are implementing integrated thinking inside the organisation to report on the impact of their behaviour on their stakeholders via integrated reporting (Katsikas et al., 2016). t Our results also provide an indication that universities are able to improve their IR Content elements disclosure and "integrated thinking" and signalling strategy even without adopting the IR Framework. to signal to stakeholders how HEIs create value for society (Secundo et al., 2016; Zutshi et al., 2018; Rinaldi et al., 2018).

\section{Insert Table 6 around here}

\section{University ranking and total IR disclosure framework}

Model 1 of Table 6 shows that there is no significant relation between university performance position ranking in the league table $(L T R)$ and Total IR disclosure $(t=-0.16)$. Our results differ with some prior studies, which find that the higher the position ranking in league tables, the higher the disclosure for performance, student satisfaction and graduate`s employment rate. The reason for this could be that we have not used the full data of UK universities, and so repeating this test with the full data may give a different result. Also, there is a debate around the issue of university rankings, particularly for post-1992 universities. Maringe (2009) argues that for lower-ranked universities, the ranking of specific subject/ school and other qualities can be a competitive advantage and can account for their scope internationally. The result for this data of universities implies that there is no relation between university ranking and level of disclosure on IR. Thus, we reject H3: (There is a positive relation between university performance position ranking in league tables and the level of disclosure on IR content elements). Our results are in line with the findings of the prior study of Hassan et al. (2019) 
that investigated UK HEIs and we support their recommendation that the British Universities Finance Directors Group (BUFDG), may consider developing voluntary IR guidance in a clear, consistent, concise and comparable format. This might allow the connections between departments via integrated thinking to provide a full reflection to stakeholders-signalling theory-.

HEI governing board size and Total IR disclosure framework

The findings of Models 1 of Table 6 show that there is a positive relationship between the number of members of the HEIs governing board (BSIZE) and Total IR disclosure, however, this relationship is not significant statistically $(t=0.71)$. This result is in line with prior studies which found no relation between HEI governing board size and Total IR disclosure (Ntim et al., 2017; Gallego-Alvarez et al., 2011). This provides support for H4: (There is no relation between university governing board size and the level of disclosure on IR content elements). Our results are in line with the prior study of Hassan et al. (2019) that investigated IR content elements in UK HEIs. Our interpretation for the above result is that it might be the board size as one of corporate governance $(\mathrm{CG})$ variables is not enough to measure this relationship and future research can look at more comprehensive CG variables such as gender, duality to be able to judge and also the small size of the population might affect our results.

\section{Additional analyses}

In this section, we carry out a set of additional analyses that aim at determining the robustness of the main results from the previous section. First, we use random-effects regression analysis (Alnabsha et al., 2018; Elamer and Benyazid, 2018; Ntim et al., 2017) to investigate whether HEI specific features influence Integrated Reporting (IR) disclosure. Omitted variables are a probable source of endogeneity in our study context. HEIs with certain features could choose to disclose more information about integrated reporting. Reverse causality is another potential 
source of endogeneity. In that occasion, the OLS regression in Model 1 of Table 6 would be biased. To deal with endogeneity, we use a random-effects regression as follows:

TOTAL $=\beta_{0}+\beta_{1} E S T B+\beta_{2} I R F A+\beta_{3} L T R+\beta_{4} B S I Z E+\beta_{5} S I Z E+\beta_{6} G W T H+$

$\beta_{7} F U N D+\beta_{8} L I Q D+\beta_{9} T E A+\delta_{i t}+\varepsilon_{i t}$

where everything else remains unaffected as stated in equation (2) and Table $1 . \delta$ is the University-year specific effects, and $\varepsilon$ is the error term. The results are reported in Model 2 of Table 6. These results are highly similar to those represented in Model 1 of Table 6, suggesting that our results seem to be robust to the potential endogeneities that may be affected by omitted variable bias or/and reverse causality.

Second, we further address potential endogeneities that may be affected by omitted variable bias by estimating two-stage least square (Elamer et al., 2018). We use the instrumented variables of the $L T R$ and BSIZE as and re-run equation (2) as follows:

$$
\begin{aligned}
& \text { TOTAL }=\beta_{0}+\beta_{1} E S T+\beta_{2} I R F A+\widehat{\beta}_{3} L T R+\widehat{\beta}_{4} B S I Z E+\beta_{5} S I Z E+ \\
& \beta_{6} G W T H+\beta_{7} F U N D+\beta_{8} L I Q D+\beta_{9} T E A+\delta_{i t}+\varepsilon_{i t}
\end{aligned}
$$

where everything else remains unaffected as stated in equation (2) except that we use the instrumented part of the LTR and BSIZE. The results are reported in Model 3 of Table 6 . These results are also similar to those presented in Model 1 of Table 6, indicating that our findings appear to be robust to potential endogeneity that may be caused by omitted variables bias. Third, to ascertain the assumption underlying our OLS regression model that all the unobserved heterogeneities may affect the correlation between the governance variables and the error term is invariable over time, we calculate a lagged estimator as proposed by Ntim et al. (2017). The findings are reported in Model 4 of Table 6. Again, we find the results indicate a positive and statistically significant relationship among the ESTB, IRFA and TOTAL indices. These results 
are also largely similar to those reported in Model 1 of Table 6, and thereby implying that our results are not strongly affected by potential endogeneity problems that may be caused by simultaneity.

\section{Conclusions}

Despite the wide range and significant impact of the activities undertaken at universities, they have tended to lag behind the rest of the corporate world when it comes to identifying and communicating their activities and impacts to the diverse groups of stakeholders that are involved in their existence. To bridge the gap between stakeholder expectations and organisational communication style regarding transparency and conciseness the IR framework was developed (IIRC, 2013). The main motivation for this study is that the unique nature of HEI challenges makes the connection and the interdependence between its departments, through integrated thinking, crucial to provide relevant information to stakeholders on value creation. We conceptualize integrated thinking as an internal process that organizations can follow to increase the level of disclosure on integrated reporting that will be used as a communication tool with stakeholders. In doing so, our paper contributes to the link between integrated reporting and integrated thinking research (Katsikas et al., 2016; Adams, 2017; Rinaldi et al., 2018) by investigating whether the disclosure of IR content elements is a reflection of implementing integrated thinking approach in HEIs (Higgins et al., 2019; Stacchezzini et al., 2019; Adams, 2018). Our paper also introduces signalling theory to describe the strategic thinking of HEIs that communication via integrated thinking can close the gap between the organization and its stakeholders and enhance its credibility (Zutshi et al., 2018; Rinaldi et al., 2018). This might enable these HEIs to live their story rather merely telling it (CIMA, 2017). Our results support the idea that integrated thinking is contributing to enhance the level of disclosure on IR content elements in HEIs. Our results are in line with the prior studies that IIRC's success is due to its ability to take advantage of a favourable momentum 
when corporate reporting was already beginning to become more integrated in practice before issuing the IR Framework (Adams et al., 2016; La Torre et al., 2019). Our results when measuring the relationship between IR and IR adoption indicated that universities are able to improve their disclosure and "integrated thinking" and signalling strategy even without adopting the IR Framework

Using recent data from three financial periods for 26 HEIs in Scotland, Northern Ireland and Wales, the findings indicate that there are disparities in IR content elements disclosure. The overall score is 29.09 percent. Analysis over the three financial periods 2013/14, 2014/15 and 2015/16 with independent variables and control variables produced a score of $(53.53 \%)$ whereas this is lower $(48.07 \%)$ with all independent variables but without the inclusion of the control variables. This appears to be very low in comparison with other research results on voluntary disclosure in HEI sector; 44.02\% from 130 UK HEI (Ntim et al., 2017); and 56.9\% from 78 Spanish HEIs (Gallego-Alvarez et al., 2011). Akin to the business organisational sector, the lack of IR content element disclosure could be due to the HEI lack of experts and/or lack of resources to produce an integrated report appropriately. This study focussed on HEI annual report disclosure which does not consider the possibility that HEIs perhaps rely more on other forms of public communication (website, press release, social media). From a methodological point of view, the disclosure index is constructed based on the IR framework produced by the IIRC, (2013). However, the IR framework is in a period of infancy and still requires a lot of dialogue to support implementation in the HEI sector (Veltri and Silvestri, 2015). In the UK HEI sector, professional bodies are actively engaged to support IR framework adoption and integrated report preparation (BUFDG, 2016, 2017).

The findings have important policy, regulatory, managerial and international implications. First, the results will be of interest to policymakers and regulators to assess the benefits of voluntary implementation of IR at HEIs in order to provide evidence for the 
possibility of the mandatory implementation of IIRC guidelines. Second, our results will be of interest to managers at universities that wish to follow these new trends. The findings can serve as a learning process for institutions interested in implementing integrated reporting. Third, our results are important to other stakeholders to further encourage universities, through their institutionalised requirements, to explicitly address integrated reporting issues in their reporting as this will increase their impact.

This study has some limitations. The use of the weighted index may need more simplification and may be affected by judgement in the selection of content, however, it has been used before (Cheung et al, 2010). Future research can focus on using an unweighted index and compare the results with our study. The study is based on a data of HEIs from Scotland, Northern Ireland and Wales and the findings could be more robust by including all UK HEI or HEI in other countries. Future research can extend this to focus on all UK HEIs. The study is based on IR content elements only and could be extended to include the fundamental concept and basic principles of the IR framework. Future research can look at other aspects of the IR framework such as reporting guidelines and can also include HEI core activities (such as teaching and learning, research and internationalisation) which have been omitted from this study. These factors should be examined in more depth by future researchers both nationally and internationally which could extend the research findings. The study focused on some regions (Scotland, Northern Ireland and Wales) in one country (UK). Future research should extend our work to be examined internationally and it might be more interesting to compare between voluntary disclosures of IR to other HEIs in other countries which IR is mandatory, such as South Africa. 


\section{References}

Aburaya, R. (2012), "The relationship between corporate governance and environmental disclosure: UK evidence". Doctoral dissertation, Durham University, available at: https://www.etheses.dur.ac.uk (accessed 3 January 2018).

Adams, C. (2015), “The International Integrated Reporting Council: A call to action”, Critical Perspectives on Accounting, Vol. 27, pp. 23-28.

Adams, C. (2017), "The Sustainable Development Goals, integrated thinking and the integrated report", available at: https://www.integratedreporting.org/resources/sdgs-integrated-thinkingand-the-integrated-report/ (accessed 18 November 2018).

Adams, C. (2018), "Let's talk value: How universities create value for students, staff and society" Leadership Foundation for Higher Education, available at: https://www.lfhe.ac.uk (accessed 6 January 2019).

Adams, S. and Simmnet, R. (2011), "Integrated Reporting: An opportunity for Australia`s not-for-profit sector”, Australian Accounting Review, Vol. 21 No. 3, pp. 292-301.

Ahmed Haji, A. and Anifowose, M. (2017), "Initial trends in corporate disclosures following the introduction of integrated reporting practice in South Africa", Journal of Intellectual Capital, Vol. 18 No. 2, pp. 373-399.

Al-Htaybat, K. and Alberti-Alhtaybat, L. (2018), "Integrated thinking leading to integrated reporting: Case study insights from a global player". Accounting, Auditing \& Accountability Journal, Vol. 31 No. 5, pp. 1435-1460.

Alnabsha, A., Abdou, H. A., Ntim, C. G., and Elamer, A. A. (2017), "Corporate boards, ownership structures and corporate disclosures: Evidence from a developing country", Journal of Applied Accounting Research, Vol. 19 No. 1, pp. 20-41.

Alshbili, I., Elamer, A. A., and Beddewela, E. (2019), "Ownership types, corporate governance and corporate social responsibility disclosures: Empirical evidence from a developing country", Accounting Research Journal, Forthcoming, available at: https://doi.org/10.1108/ARJ-03-2018-0060. (accessed 7 July 2019).

Altenburger, O. and Schaffhauser-Linzatti, M. (2014), "Integrated reporting for universities? Asset Dynamics), pp. 2705-2712.

Ayoubi, R.M. and Massoud, H.K. (2007), "The strategy of internationalization in universities: A quantitative evaluation of the intent and implementation in UK universities". International Journal of Educational Management, Vol. 21 No. 4, pp. 329-349.

Bananuka, J., Tumwebaze, Z. and Orobia, L. (2019), "The adoption of integrated reporting: a developing country perspective", Journal of Financial Reporting and Accounting, Vol. 17 No.1, pp. 2-23.

Bartocci, L. and Picciaia, F. (2013), "Towards integrated reporting in the public sector", in Busco, C., Frigo, M.L., Riccaboni, A., Quattrone, P. (Eds) (2013), Integrated Reporting. Concepts and Cases that Redefine Corporate Accountability, Springer, London, pp. 191-204. 
Berbegal-Mirabent, J. and Ribeiro-Soriano, D.E. (2015), "Behind league tables and ranking systems: a critical perspective of how university quality is measured", Journal of Service Theory and Practice, Vol. 25 No. 3, pp. 242-266.

Brusca, I., Labrador, M. and Larran, M. (2018), "The challenge of sustainability and integrated reporting at universities: A case study”, Journal of Cleaner Production, Vol. 188 (1st July 2018), pp. 347 - 354.

BUFDG (2016), "Progress on latest <IR $>$ project", available at: https://www.bufdg.ac.uk/resources/news/view?g=202eb51d-0903-4c1c-b3ab-9e2f1e27e7f9 (accessed 15 August 2018).

BUFDG (2017), "Phase 2 report on Integrated Reporting is published", available at: https://www.bufdg.ac.uk/resources/news/view?g=6f0aebb3-9fb6-4f58-9a48-

670726e5b409\&t=Phase\%202\%20report\%20on\%20Integrated\%20Reporting\%20is\%20publi shed (accessed 15 August 2018).

Burke, J.J. and Clark, C.E. (2016), "The business case for integrated reporting: insights from leading practitioners, regulators, and academics", Business Horizons, Vol. 59 No. 3, pp. 273 283.

Camilleri, M. (2018), “ Theoretical insights on integrated reporting”, Corporate Communications: An International Journal, Vol. 23 No. 4, pp. 567-581.

Carpenter, V.L. and Feroz, E.H. (2001), "Institutional theory and accounting rule choice: an analysis of four US state governments' decisions to adopt generally accepted accounting principles", Accounting, Organizations and Society, Vol. 26 No. 7-8, pp. 565-596.

Cavicchi, C., Oppi, C. and Vagnoni, E. (2019), " On the feasibility of integrated reporting in healthcare: a context analysis starting from a management commentary", Journal of Management and Governance, Vol. 23 No. 4, pp. 1-27.

Cheng, M., Green, W., Conradie, P., Konishi, N. and Romi, A. (2014), “The international integrated reporting framework: key issues and future research opportunities". Journal of International Financial Management \& Accounting, Vol. 25 No. 1, pp. 90-119.

Cheung, Y.L., Jiang, P. and Tan, W. (2010), “A transparency disclosure index measuring disclosures: Chinese listed companies", Journal of Accounting and Public Policy, Vol.29 No. 3, pp. 259-280.

Christie, F. (2016), "The reporting of university league table employability rankings: a critical review”, Journal of Education and Work, Vol. 30 No. 4, pp. 403-418.

CIMA. (2017), "Integrated Thinking: Aligning Purpose and Sustainable Performance", Available at: https://integratedreporting.org/resource/cima-global-academic-researchprogram-integrated-thinking/ (accessed 18 January 2018).

Clegg, S. and Hardy, C. (2005), Studying Organisation Theory \& Method, Sage Publications, London, UK. 
Cohen, S. and Karatzimas, S. (2015), "Tracing the future of reporting in the public sector: introducing integrated popular reporting", International Journal of Public sector Management, Vol. 28 No. 6, pp. 449 - 460.

Connelly, B., Certo, S.T., Ireland, R.D., Reutzel, C.R., (2011), "Signalling theory: a review and assessment", Journal of Management, Vol. 37 No.1, pp. 39-67.

Del Baldo, M. (2017), "The implementation of integrated reporting $<\mathrm{IR}>$ in SMEs: insights from a pioneering experience in Italy”, Meditari Accountancy Research, Vol. 25 No. 4, pp. 505-532.

Dumay, J., (2016), "A critical reflection on the future of intellectual capital: from reporting to disclosure", Journal of Intellectual Capital, Vol. 17 No. 1, pp. 168-184.

Elamer, A. A., and Benyazid, I. (2018), "The impact of risk committee on financial performance of UK financial institutions", International Journal of Accounting and Finance, Forthcoming. Available at SSRN: https://ssrn.com/abstract=3140917(accessed 30 March 2018).

Elamer, A. A., Ntim, C. G., Abdou, H. A., Zalata, A., and Elmagrhi, M. H. (2019), "The impact of multi-layer governance on bank risk disclosure in emerging markets: The case of Middle East and North Africa", Accounting Forum, Forthcoming. https://doi.org/10.1080/01559982.2019.1576577

Elamer, A. A., Ntim, C. G., and Abdou, H. A. (2017), "Islamic governance, national governance, and bank risk management and disclosure in MENA countries" Business \& Society, https://doi.org/10.1177/0007650317746108 (accessed 30 March 2018).

Elmagrhi, M. H., Ntim, C. G., Elamer, A. A., and Zhang, Q. (2019), “A study of environmental policies and regulations, governance structures and environmental performance: The role of female directors", Business Strategy and the Environment, Vol. 28 No. 1, pp. 206-220.

Feng, T., Cummings, L. and Tweedie, D. (2017), "Exploring integrated thinking in integrated reporting: an exploratory study in Australia”, Journal of Intellectual Capital, Vol. 18 No. 2, pp. 330-353.

Ferrero-Ferrero, I., Fernández-Izquierdo, M.Á., Muñoz-Torres, M.J. and Bellés-Colomer, L. (2018), "Stakeholder engagement in sustainability reporting in higher education: an analysis of key internal stakeholders' expectations", International Journal of Sustainability in Higher Education, Vol. 19 No. 2, pp. 313-336.

Fonseca, A., Macdonald, A., Dandy, E. and Valenti, P. (2011), "The state of sustainability reporting at Canadian universities", International Journal of Sustainability in Higher Education, Vol. 12 No. 1, pp. 22-40.

Gallego-Alvarez, I., Rodríguez-Domínguez, L. and García-Sánchez, I.M. (2011), "Information disclosed online by Spanish universities: content and explanatory factors", Online Information Review, Vol. 35 No. 3, pp. 360-385. 
Gamage, P., Sciulli, N., (2017), "Sustainability reporting by Australian universities". Australian Journal of Public Administration, Vol. 76 No. 2, pp. 187-203.

Garanina, T. and Dumay, J. (2017), "Forward-looking intellectual capital disclosure in IPOs: Implications for intellectual capital and integrated reporting”, Journal of Intellectual Capital, Vol.18 No. 1, pp. 128-148.

Gibbons, S., Neumayer, E. and Perkins, R. (2015), "Student satisfaction, league tables and university applications: evidence from Britain", Economics of Education Review, Vol. 48, pp. 148-164.

Gunarathne, N. and Senaratne, S. (2017), "Diffusion of integrated reporting in an emerging South Asian (SAARC) nation", Managerial Auditing Journal, Vol. 32 No. 4/5, pp. 524-548.

Guthrie, J. (2001), "The management, measurement and the reporting of intellectual capital", Journal of intellectual capital, Vol. 2 No. 1, pp. 27 - 41.

Guthrie, J., Manes-Rossi, F. and Orelli, R. L. (2017), "Integrated Reporting and Integrated Thinking in Italian public sector organisations", Meditari Accountancy Research, Vol. 25 No. 4, pp. 553-573.

Hassan, A., Adhikariparajuli, M., Fletcher, M. and Elamer, A. (2019), “ Integrated reporting in UK higher education institutions", Sustainability Accounting, Management and Policy Journal, ISSN: 2040-8021, available at: https://www.emerald.com/insight/content/doi/10.1108/SAMPJ-03-2018-0093/full/html (accessed 5 October 2019).

Hassan, A., and Guo, X. (2017), "The relationships between reporting format, environmental disclosure and environmental performance: An empirical study". Journal of Applied Accounting Research, Vol. 18 No.4, pp. 425-444.

Higgins, C., Stubbs, W., Tweedie, D. and McCallum, G. (2019), "Journey or toolbox? Integrated reporting and processes of organisational change," Accounting, Auditing \& Accountability Journal, Vol.32 No.6, pp. 1662-1689.

Hinson, R., Gyabea, A. and Ibrahim, M. (2015), "Sustainability reporting among Ghanaian universities", South African Journal for Communication Theory and Research, Vol. 41 No. 1, pp. 22-42.

Humphrey, C., O'Dwyer, B. and Unerman, J. (2017), "Re-theorizing the configuration of organizational fields: the IIRC and the pursuit of 'Enlightened' corporate reporting", Accounting and Business Research, Vol. 47 No.1, pp. 30-63.

IIRC (2013), "The Integrated Reporting Framework", available at: https://integratedreporting.org/resource/international-ir-framework/ (accessed 16 January 2018).

Jensen, J.C. and Berg, N. (2012), "Determinants of traditional sustainability reporting versus integrated reporting. An institutionalist approach", Business Strategy and the Environment, Vol. 21 No. 5, pp. 299-316. 
Jiang, N. and Carpenter, V. (2013), "A case study of issues of strategy implementation in the internationalization of higher education", International Journal of Educational Management, Vol. 27 No. 1, pp. 4-18.

Katsikas, E., Rossi, F.M. and Orelli, R.L. (2016), Towards integrated reporting: Accounting change in the public sector, Springer International Publishing, Cham, Switzerland.

King Report IV, (2016), Corporate Governance for South Africa 2016. available at: https://www.oidsa.co.za/resource/resmgr/king/_iv_Report/IoDSA_King_IV_Report_-

_WebVe.pdf (accessed 25 February 2018).

Liu, Z., Jubb, C. and Abhayawansa, S. (2019), "Analysing and evaluating integrated reporting: Insights from applying a normative benchmark" Journal of Intellectual Capital, Vol. 20 No. 2, pp. 235-263.

Lomas, L. (2006), "The locus of power in UK universities: Its impact on educational development centres", Active Learning in Higher Education, Vol. 7 No. 3, pp. 243-255.

Low, M., Samkin, G. and Li, Y. (2015), "Voluntary reporting of intellectual capital: comparing the quality of disclosures from New Zealand, Australian and United Kingdom universities", Journal of Intellectual Capital, Vol. 16 No. 4, pp. 779-808.

Lozano, R. M. and Tirado-Valencia, P. (2016), "Do industrial companies respond to the guiding principles of the Integrated Reporting framework? A preliminary study on the first companies joined to the initiative. Spanish Accounting Review, Vol. 19 No. 2, pp. 252-260.

Mahoney, L. S. (2012), “Standalone CSR reports: A Canadian analysis”. Issues in Social and Environmental Accounting, Vol. 6 No. 1, pp. 4-25.

Mahoney, L. S., Thorne, L., Cecil, L., and LaGore, W. (2013), “A research note on standalone corporate social responsibility reports: Signalling or greenwashing?" Critical Perspectives on Accounting, Vol. 24 No. 4, pp. 350-359.

Maringe, F. (2009), "Strategies and challenges of internationalisation in HE: An exploratory study of UK universities", International Journal of Educational Management, Vol. 23 No. 7, pp. 553-563.

Maroun, W. (2018), "Modifying assurance practices to meet the needs of integrated reporting: the case for interpretive assurance", Accounting, Auditing \& Accountability Journal, Vol. 31 No. 2, pp. 400-427.

Mass, K., Schaltegger, S. and Crutzen, N. (2016), "Integrating corporate sustainability assessment, management, management accounting, control, and reporting”, Journal of Cleaner Production, Vol. 136 (Part A, 10 November 2016), pp. 237-248.

Massingham, R., Massingham, P. R. and Dumay, J. (2019), "Improving integrated reporting: A new learning and growth perspective for the balanced scorecard", Journal of Intellectual Capital, Vol. 20 No. 1, pp. 60 - 82. 
Melloni, G., Caglio, A. and Perego, P. (2017), "Saying more with less? Disclosure conciseness, completeness and balance in Integrated Reports", Journal of Accounting and Public Policy, Vol. 36 No. 3, pp. 220-238.

Menard, S. (2018), Applied Logistic Regression Analysis. $2^{\text {nd }}$ ed., Sage Publications, London, UK.

Mio, C., Marco, F. and Pauluzzo, R. (2016), “Internal application of IR principles: Generali's internal integrated reporting", Journal of Cleaner Production, Vol. 139 (2016), pp. 204-218.

Montecalovo, M., Ferneti, F. and De Villiers, C. (2018), "The potential of integrated reporting to enhance sustainability reporting in the public sector", Public Money \& Management, Vol. 38 No. 5, pp. 365 - 374.

Ntim, C.G., Soobaroyen, T. and Broad, M.J. (2017), "Governance structures, voluntary disclosures and public accountability: The case of UK higher education institutions", Accounting, Auditing \& Accountability Journal, Vol. 30 No. 1, pp. 65-118.

Oll, J. and Rommerskirchen, S. (2018), "What's wrong with integrated reporting? A systemic review”, Systemic Management Forum, Vol. 26 No. 1-4, pp. 1-34.

Paloma Sánchez, M., Elena, S. and Castrillo, R. (2009), "Intellectual capital dynamics in universities: a reporting model”, Journal of Intellectual Capital, Vol. 10 No. 2, pp. 307-324.

Pavlopoulos, A., Magnis, C. and Iatridis, G.E. (2017), "Integrated reporting: Is it the last piece of the accounting disclosure puzzle?", Journal of Multinational Financial Management, Vol. 41, pp. 23-46.

Perego, P., Kennedy, S. and Whiteman, G. (2016), "A lot of icing but little cake? Taking integrated reporting forward”, Journal of Cleaner Production, Vol. 136, pp. 53-64.

Ramirez, M., (2015), "Commitments of university leaders to the Talloires declaration: are they evidenced in industrial design teaching and learning"? In: Filho, W., Brandli, L., Kuznetsova, O., Paco, A. (Eds.), Integrative Approaches to Sustainable Development at University Level, World Sustainability Series. Springer, Berlin, pp. 225 - 244.

Reimsbach, D., Hahn, R. and Gürtürk, A. (2017), "Integrated reporting and assurance of sustainability information: An experimental study on professional investors' information processing”, European Accounting Review, Vol. 26 No. 1, pp. 1-23.

Rinaldi, L., Unerman, J. and De Villiers, C. (2018), "Evaluating the integrated reporting journey: insights, gaps and agendas for future research", Accounting, Auditing \& Accountability Journal, Vol. 31 No. 5, pp. 1294 - 1318.

Rowbottom, N. and Locke, J. (2015), "The emergence of $<\mathrm{IR}>$ ", Accounting and Business Research, Vol. 46 No. 1, pp. 83-115.

Ruiz-Lozano, M. and Tirado-Valencia, P. (2016), "Do industrial companies respond to the guiding principles of the integrated reporting framework? A preliminary study on the first companies joined to the initiative", Spanish Accounting Review, Vol. 19 No. 2, pp. 252-260. 
Sangiorgi, D. and Siboni, B. (2017), "The disclosure of intellectual capital in Italian universities: What has been done and what should be done", Journal of Intellectual Capital, Vol. 18 No. 2, pp. 354-372.

Secundo, G., Dumay, J., Schiuma, G., Passiante, G., (2016), "Managing intellectual capital through a collective intelligence approach: An integrated framework for universities", Journal of Intellectual. Capital, Vol. 17 No. 2, pp. 298 - 319.

Soh, D.S., Leung, P. and Leong, S. (2015), "The development of integrated reporting and the role of the accounting and auditing profession", In, Social Audit Regulation, Springer, Chamber., pp. 33-57.

Solomon, J. and Maroun, W. (2012), "Integrated reporting: the influence of King III on social, ethical and environmental reporting", available at:

https://www.accaglobal.com/corporatereporting (accessed 2 December 2015).

Stacchezzini, R., Florio, C., Sproviero, A. F. and Corbella, S. (2019), “An intellectual capital ontology in an integrated reporting context" Journal of Intellectual Capital, Vol. 20 No. 1, pp. 83-99.

Stubbs, W. and Higgins, C. (2014), "Integrated reporting and internal mechanisms of change", Accounting, Auditing \& Accountability Journal, Vol. 27 No. 7, pp. 1068-1089.

Taj, S., (2016), "Application of signalling theory in management research: Addressing major gaps in theory”, European. Management. Journal, Vol. 34 No. 4, pp. 338-348.

Trébucq, S. and Magnaghi, E. (2017), "Using the EFQM excellence model for integrated reporting: A qualitative exploration and evaluation", Research in International Business and Finance, Vol. 42 (December 2017), pp. 522 - 531.

Veltri, S. and Silvestri, A. (2015), "The Free State University integrated reporting: a critical consideration", Journal of Intellectual Capital, Vol. 16 No. 2, pp. 443-462.

Verrecchia, R., (2001), "Essays on disclosure", Journal of Accounting and Economics, Vol. 32, pp. 91-180.

Wee, M, Traca, A., Krug, L., Aerts, W., Pink, P. and Tilling, M. (2016), "Factors affecting preparers` and auditors` judgements about materiality and conciseness in integrated reporting", available at: https://www.accaglobal.com/corporatereporting (accessed 16 October 2017).

Zutshi, A. and Creed, A (2018), "Declaring Talloires: Profile of sustainability communications in Australian signatory universities", Journal of Cleaner Production, Vol. 187, pp. 687-698. 
Tables

Table 1: Summary of variables and measurement

\begin{tabular}{|c|c|c|}
\hline Variables & Acronym & Definitions and coding. \\
\hline $\begin{array}{l}\text { Dependent } \\
\text { Variable: } \\
\text { Total IR content } \\
\text { elements' } \\
\text { Disclosure Score }\end{array}$ & TOTAL & $\begin{array}{l}\text { Total IR Content Elements Disclosure Score. Where, TOTAL - is the IR } \\
\text { content elements disclosure score containing } 56 \text { items based on } 8 \text { main } \\
\text { themes (see appendix } 1 \text { for more details), including: (1) Organisational } \\
\text { Overview and External Environment (OEE) including } 7 \text { items; (2) } \\
\text { Governance (GVN) containing } 7 \text { items; (3) Value Creation Model } \\
\text { (VCM) covering } 7 \text { items; (4) Risk and Opportunity (RO) entailing } 7 \\
\text { items; (5) Strategy and Resource Allocation (SRA) including } 7 \text { items; (6) } \\
\text { Performance (PM) containing } 7 \text { items; (7) Outlooks (OLK) covering } 7 \\
\text { items and ( } 8 \text { ) Basis of Preparation and Presentation (BPP) covering } 7 \\
\text { items. All ( } 8 \text { themes X } 7 \text { items) } 56 \text { items have a score threshold of } 0 \text { to } 3 \text {, } \\
\text { resulting in a total potential score of (56X3) } 168 \text {. Where no disclosure = } \\
0 \text {, descriptive disclosure without any link to strategy, governance, } \\
\text { performance and prospect = 1, descriptive disclosure and link with all } \\
\text { strategy, governance, performance and prospect compare with historic } \\
\text { position = 2, descriptive disclosure linked with all strategy, governance, } \\
\text { performance and prospect compare with historic, present and future } \\
\text { position = 3. }\end{array}$ \\
\hline $\begin{array}{l}\text { Independent } \\
\text { Variables related } \\
\text { to Higher } \\
\text { Education sector } \\
\text { characteristics }\end{array}$ & $\begin{array}{l}\text { ESTB } \\
\text { IRFA } \\
\text { LTR } \\
\text { BSIZE }\end{array}$ & $\begin{array}{l}\text { Establishment of HEI: } 1 \text {, If an HEI is established before 1992, } 0 \\
\text { otherwise; } \\
\text { Integrated Reporting Framework Adoption: 1, If an HEI adopted IR } \\
\text { Framework, } 0 \text { otherwise; } \\
\text { League Table Position Ranking: Measured by performance Position } \\
\text { Ranking in Complete University Guide League Table } \\
\text { Number of members in HEI governing board. }\end{array}$ \\
\hline $\begin{array}{l}\text { Control } \\
\text { Variables }\end{array}$ & $\begin{array}{l}\text { SIZE } \\
\text { GWTH } \\
\text { FUND } \\
\text { LIQD } \\
\text { TEA }\end{array}$ & $\begin{array}{l}\text { Size measured by Total Assets } \\
\text { Growth measured by the Percentage of current year's total income minus } \\
\text { previous year's total income to previous year's total income } \\
\text { Funding measured by Percentage of total annual council funding income } \\
\text { to total annual income } \\
\text { Liquidity measured by Current Assets divided by Current Liabilities } \\
\text { Total endowment measured by the Percentage of total annual } \\
\text { endewsment assets to total annual assets. }\end{array}$ \\
\hline
\end{tabular}


Table 2: Descriptive statistics of study variables

\begin{tabular}{|c|c|c|c|c|c|c|c|c|c|}
\hline Variable & $\underset{\mathbf{n}}{\text { Media }}$ & Mean & Range & $\begin{array}{l}\text { Std. } \\
\text { Dev. }\end{array}$ & Min & Max & $25 \%$ & $50 \%$ & $75 \%$ \\
\hline \multicolumn{10}{|c|}{ Dependent variable } \\
\hline $\begin{array}{l}\text { Total IR } \\
\text { Score }\end{array}$ & 57.00 & - & 79.00 & - & 26.00 & 105.00 & 44.00 & 57.00 & 71.00 \\
\hline $\begin{array}{l}\text { Theme (1) } \\
\text { OEE }\end{array}$ & 10.00 & - & 11.00 & - & 5.00 & 16.00 & 8.00 & 10.00 & 12.00 \\
\hline $\begin{array}{l}\text { Theme (2) } \\
\text { GVN }\end{array}$ & 8.00 & - & 11.00 & - & 4.00 & 15.00 & 6.75 & 8.00 & 10.00 \\
\hline $\begin{array}{l}\text { Theme (3) } \\
\text { VCM }\end{array}$ & 7.00 & - & 14.00 & - & 2.00 & 16.00 & 4.75 & 7.00 & 10.00 \\
\hline $\begin{array}{l}\text { Theme (4) } \\
\text { RO }\end{array}$ & 6.00 & - & 13.00 & - & 2.00 & 15.00 & 4.00 & 6.00 & 8.25 \\
\hline $\begin{array}{l}\text { Theme (5) } \\
\text { SRA }\end{array}$ & 9.00 & - & 16.00 & - & 2.00 & 18.00 & 6.00 & 9.00 & 12.00 \\
\hline $\begin{array}{l}\text { Theme (6) } \\
\text { PM }\end{array}$ & 8.00 & - & 14.00 & - & 3.00 & 17.00 & 6.00 & 8.00 & 10.00 \\
\hline $\begin{array}{l}\text { Theme (7) } \\
\text { OLK }\end{array}$ & 6.00 & - & 9.00 & - & 2.00 & 11.00 & 4.00 & 6.00 & 8.00 \\
\hline $\begin{array}{l}\text { Theme (8) } \\
\text { BPP }\end{array}$ & 3.00 & - & 4.00 & - & 2.00 & 6.00 & 3.00 & 3.00 & 5.00 \\
\hline \multicolumn{10}{|c|}{ Independent variables } \\
\hline LTR & 47.50 & 54.97 & 125.00 & 36.22 & 0.00 & 125.00 & 30.00 & 47.50 & 86.25 \\
\hline BSIZE & 27.00 & 28.15 & 23.00 & 4.72 & 15.00 & 38.00 & 25.00 & 27.00 & 32.00 \\
\hline \multicolumn{10}{|c|}{ Control variables } \\
\hline FUND & 32.61 & 37.55 & 335.79 & 39.32 & 2.74 & 338.53 & 18.04 & 32.61 & 45.97 \\
\hline GWTH & 4.18 & 4.79 & 93.71 & 10.34 & 13.12 & 80.59 & 0.92 & 4.18 & 7.34 \\
\hline LIQD & 1.66 & 1.78 & 4.63 & 0.92 & 0.28 & 4.91 & 1.07 & 1.66 & 2.07 \\
\hline SIZE & $\begin{array}{r}27209 \\
7.50 \\
\end{array}$ & $\begin{array}{r}42866 \\
8.94\end{array}$ & $\begin{array}{r}26895 \\
37.00 \\
\end{array}$ & $\begin{array}{r}498911 \\
.62 \\
\end{array}$ & $\begin{array}{l}1770 \\
2.00 \\
\end{array}$ & $\begin{array}{r}270723 \\
9.00 \\
\end{array}$ & $\begin{array}{r}17437 \\
2.25\end{array}$ & $\begin{array}{r}27209 \\
7.50 \\
\end{array}$ & $\begin{array}{r}51274 \\
8.00 \\
\end{array}$ \\
\hline TEA & 0.77 & 1.00 & 6.68 & 0.97 & 0.01 & 6.69 & 0.35 & 0.77 & 1.30 \\
\hline Variable & Yes (1) & No (0) & & & & & & & \\
\hline ESTB & 45 & 33 & & & & & & & \\
\hline IRFA & 5 & 73 & & & & & & & \\
\hline
\end{tabular}


Table 3: Total integrated reporting content elements' disclosure score

\begin{tabular}{|c|c|c|c|c|}
\hline & \multicolumn{3}{|c|}{ Total IR content elements' disclosure score } & \\
\hline Universities Sample & $2013 / 14$ & $2014 / 15$ & $2015 / 16$ & $\%$ increase $^{* * *}$ \\
\hline 1 & 34 & 50 & 72 & $111.76 \%$ \\
\hline 2 & 34 & 61 & 98 & $188.24 \%$ \\
\hline 3 & 35 & 38 & 47 & $34.29 \%$ \\
\hline 4 & 33 & 44 & 53 & $60.61 \%$ \\
\hline 5 & 34 & 47 & 54 & $58.82 \%$ \\
\hline 6 & 36 & 48 & 57 & $58.33 \%$ \\
\hline 7 & 55 & 55 & 66 & $20.00 \%$ \\
\hline 8 & 43 & 58 & 70 & $62.79 \%$ \\
\hline 9 & 83 & $99 * *$ & $105^{* 8}$ & $26.51 \%$ \\
\hline 10 & 44 & 55 & 79 & $79.55 \%$ \\
\hline 11 & 43 & 52 & 66 & $53.49 \%$ \\
\hline 12 & 51 & 52 & 63 & $23.53 \%$ \\
\hline 13 & $89 * *$ & 96 & 98 & $10.11 \%$ \\
\hline 14 & 40 & 47 & 57 & $42.50 \%$ \\
\hline 15 & 66 & 71 & 80 & $21.21 \%$ \\
\hline 16 & $26^{*}$ & 75 & 75 & $188.46 \%$ \\
\hline 17 & 50 & 61 & 70 & $40.00 \%$ \\
\hline 18 & 38 & 42 & 47 & $23.68 \%$ \\
\hline 19 & 44 & 57 & 71 & $61.36 \%$ \\
\hline 20 & 49 & 65 & 76 & $55.10 \%$ \\
\hline 21 & 68 & 76 & 94 & $38.24 \%$ \\
\hline 22 & 58 & 70 & 79 & $36.21 \%$ \\
\hline 23 & 68 & 80 & 80 & $17.65 \%$ \\
\hline 24 & 50 & 57 & 65 & $30.00 \%$ \\
\hline 25 & 38 & 49 & 67 & $76.32 \%$ \\
\hline 26 & 32 & $32^{*}$ & $43^{*}$ & $34.38 \%$ \\
\hline
\end{tabular}

${ }^{*}$ this refers to the university with the lowest score each year. ${ }^{* *}$ this refers to those universities with the highest score each year, $* * * \%$ of change is calculated as follows (the difference between the score in $2015 / 16$ and the score in 2013/14/the score in 2013/14). 
TTable 4: Relationship between integrated reporting disclosure index and establishment of higher education institutions

\begin{tabular}{|c|c|c|c|c|c|c|c|c|}
\hline & \multicolumn{8}{|c|}{ Linking Disclosure items' themes to Establishment of HEI (EST) } \\
\hline & \multicolumn{2}{|c|}{ Pre-1992 (15) } & \multicolumn{2}{|c|}{ Post-1992 (11) } & \multicolumn{2}{|l|}{ T. test } & \multicolumn{2}{|c|}{ Chi Square test } \\
\hline & Mean & St & Mean & St & t. test & p-value & Chi-square & p-value \\
\hline \multicolumn{9}{|l|}{ Integrated Reporting Content Elements (disclosure index components) } \\
\hline (1) Organisational Overview and External Environment (OEE) & 9.03 & 2.311 & 10.80 & 2.418 & -3.253 & $.002^{* * *}$ & 0.14 & $0.002^{* * *}$ \\
\hline (2) Governance (GVN) & 8.06 & 1.983 & 8.18 & 2.319 & -.234 & .816 & 0.511 & .814 \\
\hline (3) Value Creation Model -Business Model (VCM) & 5.91 & 2.708 & 8.16 & 3.567 & -3.031 & $.003^{* * *}$ & .263 & $.004^{* * *}$ \\
\hline (4) Risk and Opportunity (RO) & 5.39 & 2.680 & 7.11 & 3.773 & -2.232 & $.029 * *$ & .061 & $.030 * *$ \\
\hline (5) Strategy and Resource Allocation (SRA) & 8.24 & 3.419 & 9.62 & 3.473 & 1.745 & $.085 * *$ & .126 & $.085^{* *}$ \\
\hline (6) Performance (PM) & 7.48 & 2.717 & 9.18 & 2.871 & -2.632 & $.010^{* *}$ & .095 & $.011^{* *}$ \\
\hline (7) Outlook (OLK) & 4.79 & 1.949 & 7.07 & 2.349 & -4.541 & $.000 * * *$ & .006 & $.000 * * 8$ \\
\hline (8) Basis of Preparation and Presentation (BPP) & 3.45 & 1.092 & 4.22 & 1.396 & -2.623 & $.011^{* *}$ & .018 & $.011 * *$ \\
\hline Total Integrated Reporting (IR) Content elements score & 52.36 & 14.205 & 64.04 & 19.575 & -2.881 & $.005^{* * 8}$ & .541 & $.006^{* * 8}$ \\
\hline
\end{tabular}

Note. Significance levels: $p<.10 .{ }^{*} p<.05 .{ }^{* *} p<.01 .{ }^{* * *}$. 
Table 5: Correlation matrix for research variables

\begin{tabular}{|c|c|c|c|c|c|c|c|c|}
\hline & Total & LTR & BSIZE & FUND & GWTH & LIQD & SIZE & TEA \\
\hline Total & 1.00 & & & & & & & \\
\hline LTR & -0.046 & 1.00 & & & & & & \\
\hline BSIZE & 0.124 & -0.034 & 1.00 & & & & & \\
\hline FUND & 0.013 & 0.044 & -0.186 & 1.00 & & & & \\
\hline GWTH & 0.046 & $-0.400 * *$ & -0.060 & 0.100 & 1.00 & & & \\
\hline LIQD & -0.205 & -0.031 & -0.134 & -0.103 & -0.083 & 1.00 & & \\
\hline SIZE & $0.284 * *$ & $-0.337 * *$ & 0.158 & $-0.296 * *$ & 0.14 & 0.189 & 1.00 & \\
\hline TEA & -0.018 & -0.158 & -0.022 & 0.216 & 0.171 & 0.165 & 0.081 & 1.00 \\
\hline
\end{tabular}

Note. The above table contains Spearman's nonparametric correlation coefficients, Significance levels: $p<.05^{*} . p<.01 * *$. Variables are defined as follows: Total IR disclosure (TOTAL), Establishment of HEI (ESTB), Integrated reporting framework adoption (IRFA), League table position ranking $(L T R)$, Number of members in HEI governing board (BSIZE), Funding (FUND), Growth $(G W T H)$, Liquidity (LIQD), Total assets $(S I Z E)$,

Total endowment (TEA). 
Table 6: Influence of HEI specific characteristics on IR disclosure

\begin{tabular}{|c|c|c|c|c|}
\hline Variables & (1) & $(2)$ & (3) & (4) \\
\hline \multicolumn{5}{|c|}{ Panel A: Independent variables } \\
\hline \multirow[t]{2}{*}{ ESTB } & $10.967 * * *$ & 7.027 & $10.210 * *$ & $10.691 * *$ \\
\hline & $(0.008)$ & $(0.167)$ & $(0.025)$ & $(0.023)$ \\
\hline \multirow[t]{2}{*}{ IRFA } & $23.146 * * *$ & 14.384 & $20.506 * *$ & $29.339 * * *$ \\
\hline & $(0.005)$ & $(0.147)$ & $(0.021)$ & $(0.004)$ \\
\hline \multirow[t]{2}{*}{ LTR } & -0.008 & 0.029 & 0.014 & 0.050 \\
\hline & $(0.497)$ & $(0.334)$ & $(0.407)$ & $(0.2120)$ \\
\hline \multirow[t]{2}{*}{ BSZE } & 0.252 & 0.388 & 0.290 & 0.548 \\
\hline & $(0.403)$ & $(0.234)$ & $(0.255)$ & $(0.133)$ \\
\hline \multicolumn{5}{|c|}{ Panel B: Control variables } \\
\hline \multirow[t]{2}{*}{ FUND } & 0.041 & 0.029 & 0.051 & 0.025 \\
\hline & $(0.484)$ & $(0.277)$ & $(0.167)$ & $(0.287)$ \\
\hline \multirow[t]{2}{*}{ GWTH } & 0.097 & -0.066 & 0.002 & 0.093 \\
\hline & $(0.462)$ & $(0.352)$ & $(0.496)$ & $(0.307)$ \\
\hline \multirow[t]{2}{*}{ LIQD } & $-3.705 * *$ & -2.603 & -3.306 & -2.731 \\
\hline & $(0.002)$ & $(0.154)$ & $(0.162)$ & $(0.152)$ \\
\hline \multirow[t]{2}{*}{ SIZE } & 0.000 & $0.000 *$ & 0.000 & -0.000 \\
\hline & $(0.500)$ & $(0.038)$ & $(0.195)$ & $(0.492)$ \\
\hline \multirow[t]{2}{*}{ TEA } & -1.919 & $-4.032 * *$ & $-3.506^{*}$ & 2.756 \\
\hline & $(0.041)$ & $(0.027)$ & $(0.060)$ & $(0.119)$ \\
\hline \multirow{2}{*}{ _cons } & $38.271 * * *$ & $42.977 * *$ & $46.888 * * *$ & $44.455 * *$ \\
\hline & $(0.000)$ & $(0.016)$ & $(0.006)$ & $(0.012)$ \\
\hline Years & Included & Included & Included & Included \\
\hline F-value $(\chi 2)$ & $6.98 * * *$ & $20.89 * *$ & $3.37 * * *$ & $4.08 * * *$ \\
\hline $\mathrm{N}$ & 78 & 78 & 78 & 52 \\
\hline R-sq & 0.54 & 0.28 & 0.31 & 0.50 \\
\hline adj. R-sq & 0.46 & & 0.22 & 0.38 \\
\hline
\end{tabular}

Notes: The above table represents regression coefficients and $\mathrm{P}$ value in parentheses. Significance levels are $* \mathrm{p}<0.10, * * \mathrm{p}<0.05, * * * \mathrm{p}<0.01$. The Variables are defined as follows. Total IR disclosure (TOTAL), Establishment of HEI (ESTB), Integrated reporting framework adoption (IRFA), League table position ranking (LTR), Number of members in HEI governing board (BSIZE), Funding (FUND), Growth (GWTH), Liquidity (LIQD), Total assets (SIZE), Total endowment (TEA). 


\begin{tabular}{|c|c|c|c|c|c|}
\hline & & 0 & 1 & 2 & $3 * *$ \\
\hline & Organisational Overview and External Environment (OEE) & & & & \\
\hline OEEl & Vison and Misgion (VM) & & & & \\
\hline OEE2 & Operating structure, Principle Activates and Market Position & & & & \\
\hline OEE3 & Competitive environment and institution's pogition(CEP) & & & & \\
\hline OEE4 & Key quantitative information(KQI) & & & & \\
\hline OEE5 & Commercial, social, technical, environment and political environment(STPE) & & & & \\
\hline OEE6 & Reverue and change on it (RC) & & & & \\
\hline \multirow[t]{2}{*}{ OEE? } & Extemal environment and its impact on value creation(EEVC) & & & & \\
\hline & Governance (GVN) & & & & \\
\hline GVN1 & Leadership structure, diversity and regularity requirement(LDR) & & & & \\
\hline GVN2 & Different element and interaction (DEI) & & & & \\
\hline GVN3 & Executive and non-executives' role and responsibilities(ENR) & & & & \\
\hline GVN4 & Strategic decision-making process(SDM) & & & & \\
\hline GVN5 & Monitoring approach of strategic direction (MASD) & & & & \\
\hline GVN6 & Risk identification, monitoring and mitigation( $\mathrm{RMM})$ & & & & \\
\hline \multirow[t]{2}{*}{ GVN7 } & Directors remuneration determination process(DRD) & & & & \\
\hline & Value Creation Model -Business Model (VCM) & & & & \\
\hline VCMI & Main activities, strategic purpose achievement and value creation (APVA) & & & & \\
\hline $\mathrm{VCM} 2$ & Different capitals utilization to complete main activities (CUA) & & & & \\
\hline $\mathrm{VCM}$ & Main source of income (IS) & & & & \\
\hline
\end{tabular}

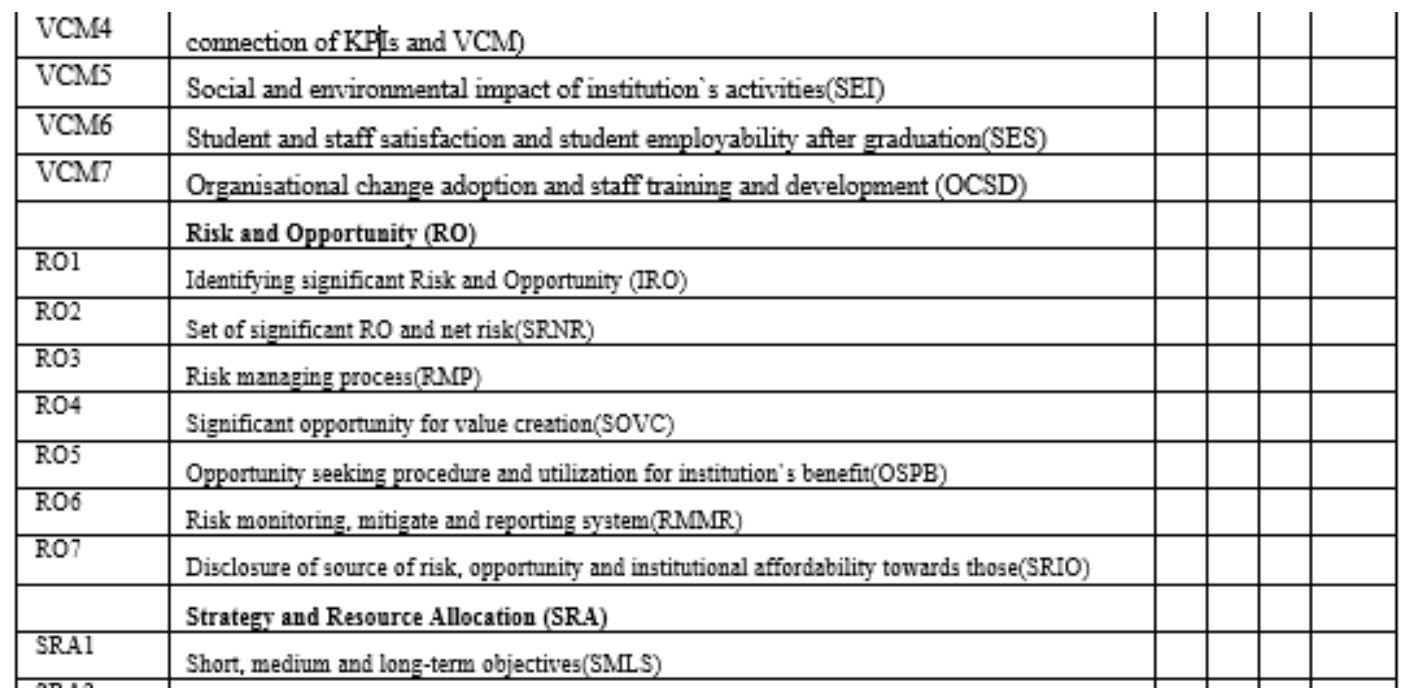




\begin{tabular}{|l|l|l|l|l|} 
SKA. & Current and planned institutional strategies(CPS) & & & \\
\hline SRA3 & Resource allocation plans to implement strategy(RAIS) & & & \\
\hline SRA4 & Financial sustainablity for short, medium and long term (FS) & & & \\
\hline SRA5 & Performence measurement for short, medium and long term(PM) & & & \\
\hline SRA6 & Sector wise institutional differentiation and reflection in strategy(IDRS) & & & \\
\hline SRA7 & Intellectual capital utilization for revenue maximization(ICRM) & & & \\
\hline & Performance (PM) & & & \\
\hline PM1 & Strategic objectives for the period and its achievement(SIA) & & & \\
\hline PM2 & Balance and complete view of performance(BCP) & & & \\
\hline
\end{tabular}

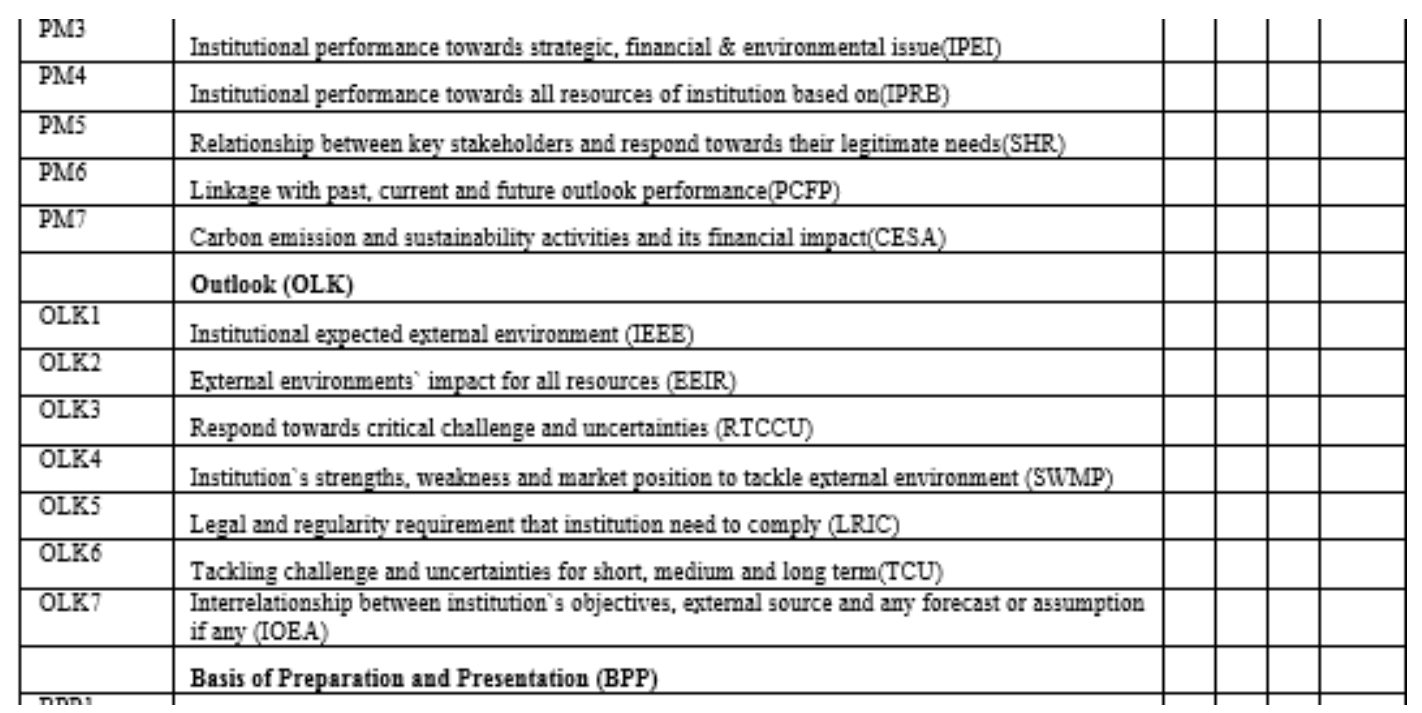

\begin{tabular}{|l|l|l|l|l|} 
& Basis of Preparation and Presentation (BPP) & & & \\
\hline BPP1 & Content of report decision process and the individuals involved on this(RCPI) & & & \\
\hline BPP2 & Disclose the individuals involved in preparation and review the report (RPR) & & & \\
\hline BPP3 & Materiality identification and measure framework (MIMF) & & & \\
\hline BPP4 & Any uncertainty for data used for report preparation (DUC) & & & \\
\hline BPP5 & Material matter identification process (MIP) & & & \\
\hline BPP6 & Materiality identification, measurement and prioritization (MIMP) & & & \\
\hline BPP7 & How inatitutions' focus on value creation form material matter (IFM) & & & \\
\hline
\end{tabular}

* No disclosure $=0$. Descriptive disclosure without any link to strategy, governance, performance and prospect $=1$, Descriptive disclosure and link with all strategy. governance, performance and prospect compare with historic position $=2$, Descriptive diaclosure linked with all strategy. governance, performance and prospect conpare with historic, present and future position $=3$ 